\title{
JEWISH ATTITUDES TO CHRISTIAN POWER IN MEDIEVAL SPAIN
}

YOM TOV ASSIS

The Hebrew University. Jerusalem

Whereas the attitude of the rulers of Christian Spain towards their Jewish subjects has been treated by various scholars ', Jewish attitudes towards royal authority and power in medieval Spain have not been systematically analysed. The Jews' attitude to Christian rulers was of little importance in comparison to the latter's views of them. However, the Jews were not deprived of political and economic influence in the country, at court and most particularly in the juderia or call, i.e. the Jewish quarter, and an attempt to examine the Jews' attitudes to Christian power is not without relevance to the study of Judeo-Christian relations in medieval Spain. Fully aware of the limited influence Jewish opinion had in actuality, it is nevertheless submitted that what the Jewish public and its leaders thought of the rulers within their quarters and in their own internal literature, is closely related to their treatment by the crown. As a matter of course, the most revelatory sources on the subject are the writings of Spanish rabbis, in responsa and commentaries. These Hebrew sources give us an insight into the Jews' political ideas and social ideologies which were reflected also in the regime prevailing in the Jewish communities ${ }^{2}$.

Some prominent Spanish rabbis expressed strong royalist sym-

1 Y. BAER, A History of the Jews in Christian Spain, trans. by L. Schoffman, Philadelphia 1966, I, pp. 111-185; A. A. Neuman, The Jews in Spain, Their Social, Political and Cultural Life during the Middle Ages, I, Philadelphia 1944, pp. 3-33; J. L. ShNEIDMAN, The Rise of the Aragonese-Catalan Empire 1200-1350, I, New York 1970, pp. 417-458.

2 The most important Hebrew sources for the history of the Jews are the Responsa. A general survey of the Responsa of Spanish rabbis may be found in H. J. ZimMELS, "The Contribution of the Sephardim to the Responsa Literature till the Beginning of the 16th Century"; in The Sephardi Heritage, ed. R. BARNETT, London 1971, pp. 376394. 
pathies and deep respect for the institution of monarchy in general. In his commentary on "You shall be free to set a king over yourself" (Deut 17:15), Nahmanides, an outstanding leader of Spanish Jewry in the thirteenth century, says that kingship among the nations is divine just as it is among the Jews. Kings, whether Jewish or gentile, rule by the grace of God and the king's reign is indicative of divine favour and consent ${ }^{3}$. A century later R. Nissîm Gerondî was even more explicit. Kings were God-sent for the sake of the welfare of the world. Kingship among the Jews and the gentiles served the same purpose, and whether sent by God or chosen by men, the kings' duty was to cater for the well-being of the world ${ }^{4}$.

The divine source of royal authority was a concept that spread in the Christian west and Spanish rabbis upheld a similar view. Thomas Aquinas was one of its best known exponents s. The Siete Partidas of Alfonso $\mathrm{X}$ of Castile is explicit on this matter:

"Vicarios de Dios son los reyes cada uno en su regno ... et los santos dixeron que el rey es señor puesto en la tierra en lugar de Dios para complir la justicia et dar a cada uno su derecho".

Alfonso $\mathrm{X}$ clearly states that any king who misuses his authority and power loses his divine right and becomes usurper ${ }^{6}$.

Nahmanides' favourable attitude is reflected in the comparison he makes between Jewish and gentile kings '. R. Šlomo ben Adret, who succeeded Nahmanides as the foremost leader of Spanish Jewry in the latter half of the thirteenth century adopted a similar view. Jewish subjects should obey them just as they do a Jewish King ${ }^{8}$. Adret adds more reasons to those suggested by Nahmanides for the Jews to respect and obey a non-Jewish king. Adret, whose responsa

${ }^{3}$ C. B. Chavel (ed.), R. Mose ben Nahman: Perus' 'al ha-Tord, Jerusalem 1960, II, p. 424, Deut 17:15: «In my opinion, the simple meaning of 'that He will choose' is that whoever reigns over the nations derives his [rule] from God".

4 L. A. Feldman (ed.), R. Nissím Gerondî: Déraśót, Jerusalem 1974, eleventh sermon.

S St. Thomas Aquinas, Summa Theologica, ed. Typographia del Senato, Roma $1886,2.2,105,1$.

6 Siete Partidas, ed. Madrid 1807, II, 1,5 and see also ibid., II, 1,10.

' R. Moš Ben Nahman, Hiddusim Baba' Batra', 55r, s.v. 'Aflliu

8 R. Šl 109. 
and novella have had a great impact on the development of the halak $\hat{a}$, showed great familiarity with the local laws and political conditions. Adret asserts that wherever the king owns the entire land may divide it as he pleases among the people who owe his full respect 9 . Although the doctrine that all land, including private land, belonged to the emperor was challenged in various countries and epochs, it was, nevertheless, most appropriate in thirteenth century Spain, where Castile and the Crown of Aragon expanded immensely their territories and their kings were engaged in the distribution of conquered lands. Adret knew well that Christians and Jews benefited from the repartimiento.

Jaime II, whose reign partly coincided with the period of Adret's leadership, is described in Jewish sources as a "righteous king". Jaime's personal feelings towards the Jews were not at all sympathetic as can be seen in his letter to his daughter Constanza which he sent in 1321 after she gave birth to a son. Following the customary congratulations for the occasion, he wrote:

We trust in God that He will save and guard him for you, but daughter, do not do as you are accustomed to do, entrust his education to the Jews ${ }^{10}$.

In view of his personal dislike of the Jews, his official Jewish policy was all the more praiseworthy. For the Jews of his realm, he was their protector who defended their rights, their lives and property as a matter of principle. His decisions, which might have offended the Jews, were counterbalanced by many others which greatly favoured them. When the kings of England and France expelled their Jews in 1290 and 1306, the Iberian kingdoms were places of refuge for the Jews. Jaime II allowed Jewish refugees from France to settle in his realm ". During the Shepherds' Crusade in 1320, the King's

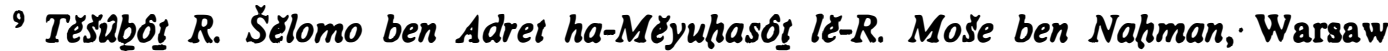
1883, [ADRET VIII], No 62.

10 A. Giménez Soler, D. Juan Manuel, Biografla y estudio critico, Zaragoza 1932, Apéndice No CCCLXXIV; J. E. MARTinez FerRando, Jaime II, su vida familiar, Barcelona 1948, II, doc. 366: «E fiamos en Dios qu'ell vos lo salvara, el vos conservara, mas filla, no fagades como acostumbrado de criarlo a consello de los judios".

$" \mathrm{Y}$. Assis, "Juifs de France réfugiés en Aragon (XIII-XIV siècles)», REJ CXLII (1983) 285-322.
} 
defence of the Jews proved to be quite efficient ${ }^{12}$. An overall view of his reign shows clearly that the Jews' appreciation of his policy towards them was more than justified.

Hebrew sources from the fourteenth century are most complimentary to the kings-counts of the Crown of Aragon. Maestre Crescas Elias, a leader of Aragonese Jewry at that time, was full of gratitude towards the kings of the land who treated the Jews well. This is what he wrote in 1346:

... and God, in his mercy, left among us a remnant, from the kingdoms that oppressed the Jews ... and, having obtained compassion, a few of us were gathered together in some of the kingdoms, as God inspired the righteous and merciful kings of Aragon, may their name be of good augury, who love justice and hate evil, their virtues have avoided persecution, disasters and hateful and horrible upheavals ... truth and peace being the foundations of their land ... may those who showed mercy on Israel, gave refuge to exiles from all corners of the world, treated them and supported them with honour, never collapse ... [God] having already put over us a just and upright king, a ruler full of the fear of God, who listens to our complaints to save us...

The king Crescas Elias referred to was Pedro IV. These words of praise could not have been merely words of flattery for they were intended for the Jewish public as they were witten in Hebrew and could have certainly used a more moderate style had he not meant them ${ }^{13}$.

This favourable attitude was the direct result of the Jewish policy of the kings of Castile and Aragon. By the thirteenth century, the Crown had emerged as the Jews' only reliable ally, while the latter proved to be the monarch's most trustworthy and efficient servants. The Jews' almost total dependence on him made them politically very weak but also safe from his point of view. This political weakness was paradoxically to become the Jews' source of power. Jaime I and Pedro III of Aragon and Fernando III and Alfonso $\mathrm{X}$ of Castile, the leaders of the renewed Reconsquista in the

12 J. MiRet y SANS, *Le massacre des Juifs de Montclús en 1320", REJ LIII (1907) 255-266.

13 F. BAER, Die Juden im christlichen Spanien, I, Aragonien und Navarra, Berlin 1929, No 224a. 
thirteenth century, made full use of the Jews in numerous fields connected with the expansion of both kingdoms. Jews were found most suitable for the colonization of the conquered territories. Despite their small number, Jewish colonists were very much in demand. Foreign Jews, from North Africa and elsewhere, were invited to settle in the new territories. The king, who granted houses and fields to the Jews, considered such property to be still his and could afford therefore to be generous. Jews in both kingdoms were employed as diplomats, interpreters, translators, financiers, administrators and physicians. In such capacities, they played a role of major importance in the Reconquista, in the political and economic life of Christian Spain. The attempt to establish a Civil Service, almost entirely composed of Jews, is a phenomenon without parallel in medieval Christian Europe. Among other things, it meant the political neutralization of the nobility and higher clergy. The reaction to Jewish influence at court put an end to Jewish involvement in politics and diplomacy in the Crown of Aragon, not in Castile, but did not terminate the special relationship between the Crown and the Jews. The latter still saw in the king their benefactor and protector ${ }^{14}$.

In the fourteenth century we may discern signs of decline in the position of the Jews in the Crown of Aragon. Municipal and ecclesiastical authorities increased their pressure on the Jews while the number of Jewish apostates grew steadily. The attacks against Jewish communities during the Black Plague in 1348 showed how precarious their status was. The king was their only protector. The representatives of the communities of Catalonia and Valencia, assembled in Barcelona in 1354, following the 1348 attacks and anti-Jewish trials and torture, decided to turn

to the throne of our great and glorious King, who together with his fathers, predecessors and family, are all righteous kings, under whose shadow we have lived among the nations. It is thanks to this that

14 For a general treatment of the subject see Y. BAER, A History, I, pp. 46-59; $111-$ 150; 162-177; for the Crown of Aragon see D. Romano, Judlos al servicio de Pedro el Grande de Aragón (1276-1285), Barcelona 1983; J. L. ShNBIDMAN, «Jews in Administration of 13th Century Aragonn, Historia Judaica XXI (1959) 37-52; Y. Assis, "Diplomatim Ythudim me-Aragonya bł-'Arsbt ha-Islam (1213-1327)m, Sefunot III [18] (1985) 11-34. 
our fathers and we have managed to survive ever since we were exiled from our land...

Their request now for royal protection was based on the pro-Jewish policy of Pedro's predecessors ${ }^{15}$.

Nowhere else in Christendom were the rabbis closer to the kings and the royal family than in Spain. These rabbis knew well the royal customs and etiquette and showed remarkable familiarity with the ruler's policy and the political conditions prevalent in the country. Some of them served the king faithfully and efficiently and won the king's confidence and esteem. R. Moše ben Nah̆man, R. Šlomo ben Adret, R. Aharon Ha-Levî de Na Clara, R. Yôm Tôb Alsibilîi, R. Nissîm Gerondî, R. Hasday Crescas, to quote the most prominent of all, entertained very close relations with the Aragonese monarchs. They had relatives, even sons, in royal courts. Nahmanides' son, for instance, was in the service of the Castilian court. On numerous occasions the kings of Castile and the Crown of Aragon turned directly to them for their opinion and advice ${ }^{16}$.

In the Spanish kingdoms the number of Jews in the service of the crown was very large. These Jewish functionaries, members of the upper classes in Jewish society, were in a position to aquaint their fellow-Jews with details on the life of the king and his family and inform them about their attitude towards Jews. The Jewish courtiers belonged to the same social stratum as most of the rabbis. The latter showed concern about the conduct of the royal officials as Jews. Attention is drawn to the brief legal compendium Seda Laderek composed by $\mathbf{R}$. Mennahem ben Zerah especially for use by Jewish courtiers who had no time to search for the specific halakôt needed while they were in attendance at court and in journeys with the king. In his introduction he writes:

15 F. BAER, Die Juden, No 253. On the anti-Jewish attacks in the territories in the Crown of Aragon see A. LOPEZ DE MENESES, "Documentos acerca de la peste negra en los dominios de la Corona de Aragón", Estudios de la Edad Media de la Corona de Aragón IV (1956) 291-447; IDEM, "Una consecuencia de la peste negra en Cataluña: el progrom de 1348»; Sefarad XIX (1959) 92-131; 321-364.

${ }^{16}$ See, for instances, J. REGNE, History of the Jews in Aragon: Regesta and Documents 1213-1327, (ed. Y. Assis), Jerusalem 1978, Nos 713, 751, 873, 881, 927, 1.192 [originally published in REJ LX-LXXVIII (1910-1924)]; F. BAER, Die Juden, Nos 115,$2 ; 116,2 ; 127$. 
When I saw that those who are in the court of our Illustrous Majesty the King act, each one in accordance with his status and position, as protectors and shelters of our people but in the circumstances and following their ambitions they lead a certain way of life, especially when they accompany the court on its journeys, lax in the observance of the commandments... ${ }^{17}$.

The royal court was thus well-known to quite a number of Jews who could form an opinion based on personal experience and knowledge.

The Talmudic principle dina' dé-malkuta dina' (the law of the kingdom is law) was partly interpreted under the impact of the sympathy the rabbis of Spain had for the king, on condition that the law applied to all the king's subjects. In the words of R. Yôm Tôb Alsibilî̀:

The agreement of the king's judge has no bearing except if the law is a fixed law of the entire kingdom and also of the Jews ${ }^{18}$.

It follows from the above that it is the law of the kingdom and not that of the king that supersedes Jewish law in certain circumstances. Thus both Nahmanides and Adret applied the Talmudic principle only in the case of a law established in the code and judicial tradition of the country and not a law legislated by the king for the needs of the hour ${ }^{19}$. Furthermore, the two greatest halakhists in thirteenth century Spain condoned and indeed required disobedience of a law that is unjust or contrary to Jewish law. In reality, the opinion of scholars on the legality of a king's law had no relevance. The king certainly did not need the rabbis' approval. However, we have reason to believe that, in certain conditions, such rabbinic opinions affected the behaviour of Jews in their daily life.

For R. Ya'aqob ben Ašer "the law of the kingdom" can only be valid if it applies to all the inhabitants of the land. Any decision that is not prescribed by law is sheer injustice ${ }^{20}$. Basing himself on

17 R. Měnahem Ben ZeRah, Seda Laderek, Warsaw 1880, p. 7.

18 Y. KAPPAH, (ed.) R. Yób Alsibilî: Še elót u-Téubbobt, Jerusalem 1959, No 53.

19 Tésubot HaRamban, No 46, in S. Assaf, Sifran sel Rišonim, p. 88; R. ŠĕLomo BEN ADRET, Hiddust'm, Baba'Batra', 55r.

${ }^{20}$ R. YA'AQOB Ben Ašer, Tur Hošen Mišpat, Hilkkit Gězela, II, Jerusalem 1959, chap. 369. 
R. Yosef Ha-Levî ibn Měgaš, Nahmanides had described such decisions as acts of violence and robbery ${ }^{21}$. As noted above, these rabbinic decisions had no relevance whatsoever from the king's point of view, but they did encourage Jews to disobey or avoid the king's laws, declared illegal by their leaders.

As noted above, the Jewish policy of the kings of Christian Spain left a deep impression on the Jewish leaders. R. Měnahem Ha-Mecîni of Perpignan, a leading figure in the fourteenth century, was most appreciative of the king's attitude towards the Jews. He witnessed the treatment of Jewish refugees from France by the king of Majorca, whose dominion included the regions of Roussillon. In fact, all Jews of Christian Spain could compare with satisfaction the treatment of the Jews of France and England by the crown and their own good fortune. It is very probable that Ha-Me'îrî's view of the Christian world in general was influenced by the good relations that existed between the Jews and the Crown in the Iberian Peninsula. For Ha-Me'irî the king's laws are not "the laws of the nations" that the Torah forbade the Israelites to follow ${ }^{22}$.

Medieval reality and Jewish law were not always in harmony. In marital law as well as in ritual matters, the law of the land was totally rejected if it contradicted Jewish law. No community gave up its right to eat kašer meat or bake its unleavened bread for Passover. Any pressure from the authorities to ignore such laws would have meant the dissolution of the community. On other hand, in matters of finance and livelihood ways and means were found to adjust the law to reality and the law of the country overrode Jewish law ${ }^{23}$. Although Adret was strongly opposed to the application of nonJewish law to matters of inheritance, in Catalonia the local laws of inheritance were widely practised among the Jews who considered the matter purely financial ${ }^{24}$. In questions of devaluation and inflation, the laws of the country superseded the halak $a^{25}$. Castilian and

${ }^{21}$ Tesubbót HaRamban, No 46, in S. AssAF, Sifran sel Rišonim, Jerusalem 1935, p. 88.

22 R. Ménahem Ha-Meíri, Bêt Ha-Bęhîra, Baba’ Qamma’ 113,2. On Ha-Me’î's view of Christianity see J. KATZ, Exclusiveness and Tolerance, New York 1961, pp. 114-128.

${ }^{23}$ H. Soloveitchick, Halaked, Kalkald wě-Dimmuy 'Asmi, Jerusalem 1985.

24 ADRET VIII, No 22.

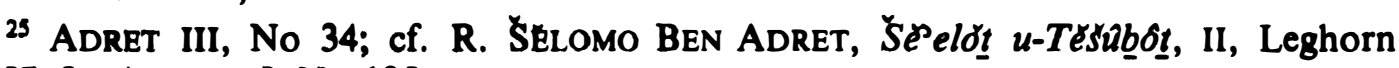
1657, [= ADRET II], No 125 . 
Aragonese communities adopted ordinances on the sale of land which were compatible with the law of the country. R. Ašer ben Yehiel justified the taqqana on the basis of the principle "the law of the kingdom is law» ${ }^{26}$. R. Nissîm Gerondî, in Catalonia, went even further and suggested that, in certain circumstances, the "law of the kingdom» in political and social fields might be superior to the laws of the Torah ${ }^{27}$.

The king's feudal lordship over land in general and its implications in daily life were well understood by Jewish jurists. On the basis of this lordship, Adret recognizes the king's right to do as he pleases in all public places, squares, roads, markets, and to build, demolish, restore and repair. R. Šlomo ben Adret showed great aptitude in making certain adjustments in his halakhic decisions to avoid a clash between the halak $a$ and the king's law ${ }^{28}$. In many instances related to finance and real estate, the king's law took precedence over Talmudic law in lawsuits between Jews. Halakhists were quite aware of the preference shown at times by Jews for the law of the land, especially when it seemed to favour them. In most cases there was little that could be done except offer a legal justification ${ }^{29}$.

The political and social system in the Christian kingdoms left its impact on the Jews' attitude to Christian rulers. In the Crown of Aragon, for instance, the question arose as to whether baronial lordship should be treated as royal authority ${ }^{30}$. In Aragon and Catalonia there were several communities in baronial domains. Hebrew sources contain evidence that some Jews made use of the feudal system and found in the political divisions and social stratification certain advantages. Some Jews emigrated from royal to baronial domains and vice versa, mostly to obtain some tax advantages. Jews who lived on noblemen's estates refused at times to submit to the judicial jurisdiction of the royal aljama. The close link between communal jurisdiction and royal authority is obvious ${ }^{31}$.

\footnotetext{
${ }^{26}$ R. ASER Ben Yehiel, Še elot u-Tesubobt, XVIII, No 16; S. Shilo, "Al Šte Taqqanôt Qahal bi-Šfarad», Sinai LXI (1967) 291-297.

27 R. Nissim Gerondl, Derraśtót, No 11.

28 ADRET II, No 134.

29 ADRET II, No 292.

${ }^{30}$ R. Sélomo Ben ADRET, Še elot u-Tesubobt, I, Bologna 1539, [= ADRET I], Nos $612,637$.

31 ADRET II, No 344.
} 
In marital matters, the situations was complicated. The king's interference in this field naturally aroused the rabbis' reaction. Rabbis were frequently asked whether it was permitted to turn to the king or his representatives to solve family and marriage problems.

In the case of halisa, i.e. when a Jew had to perform a ceremony to release his brother's childless widow, if he did not wish to marry her, the question was raised if the authorities' help could be sought to force a Jew to perform the halis $\hat{a}^{32}$. Aragonese law forbade divorce against the will of the wife and her father and prescribed capital punishment for the husband who acted against the law. Talmudic sholars had to find a solution compatible with Jewish law ${ }^{33}$. Bigamy, too, was forbidden by the law of the country but permitted by Jewish law. The ban of R. Geršom against bigamous marriages was not accepted in Spain. Ordinary Jews and rabbis found ways to obtain the king's permission to marry a second wife despite the prohibition. The king's permission was invariably based on the legality of bigamy in Jewish law ${ }^{34}$.

It is noteworthy that almost all the rabbinic authorities who applied the principle "the law of the kingdom is law", that is the supremacy of the law of the kingdom over Jewish law, to civil cases among Jews, were from Spain. They included Nahmanides, Adret, Vidal de Tolosa, Nissîm Gerondî. Spanish rabbis made a clear distinction between the law of the kingdom that applied to the entire population of the realm and the laws and norms of the people that were part of the Roman-Christian tradition. The principle dina' dermalkuta' dina' did not apply to the latter ${ }^{35}$. Jews who brought their lawsuits against other Jews to non-Jewish courts were therefore vehemently criticized ${ }^{36}$.

32 ADRET I, No 1.240.

33 ADRET I, No 1.237: «... and because there is a law of the Kingdom that sets the death penalty to anyone who divorces his wife against her will and that of her father...*. Naturally the law applied to Jews.

34 Y. Assis, “'Herem de Rabbenu Geršom' wě-Nissue Kefel bi-Š̌farad”, Zion XLVI (1981) 251-277.

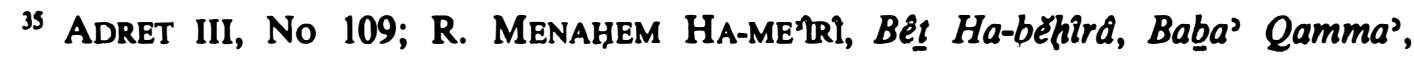
$113 b$.

36 See for instance C. B. Chavel (ed.), R. Bahye Ben Aserer: Kad Ha-Qemah, Jerusalem 1970, s.v. Dinin. For a general treatment of the subject see Y. Assis, "Y̌hade Šfarad becArkaot ha-Góyim (Ha-Meot ha-13 wð̌ha-14)", in M. BEN-SASSON, R. BONFIL \& Y. HACKER (eds.), Tarbut we-Hébrd bé-Tolédót Yisra'el wěha-'Amim, Jerusalem 1989, pp. 399-430. 
The spiritual leaders of Spanish Jewry were opposed to any jurisdiction of the Christian judiciary in marital and ritual affairs except when the established law of the country, compatible with the halak $a$, applied to the entire kingdom, including the Jews ${ }^{37}$. As in many localities in the peninsula there were no suitable dayyanim, the question arose whether a bêt-din composed of ignorant people was preferable to a properly constituted Christian court. Referring to such a situation, adret wrote to the community of Toledo that the kings of Spain authorized the Jews to try their own cases whatever the circumstances ${ }^{38}$.

While Spanish rabbis were opposed to Jewish litigants appearing in Christian courts, they did, however, recognize, under certain conditions, the validity of notarial documents. This innovation of Nahmanides was adopted by Adret as can be seen from his responsa to the communities of Lerida and Valencia ${ }^{39}$.

In Castile, the official stand of the Jews was set by R. Ašer ben Yehiel who decided that as long as the king did not issue a prohibition, Hebrew documents shoul be used. If the government forced the Jews to use the documents drawn by its agencies, these documents were to be considered valid. His son, R. Ya'aqob ben Ašer declared legal all commercial and promissory notes ${ }^{40}$. These decisions were inevitable as the need to adjust Jewish law to the prevalent circumstances became urgent.

Adret's disciples Abraham ben Šlomo Tazrat, in his Huqqat Ha-Dayyanim "1, Vidal de Tolosa, author of the Maggid Misneh on the Mišneh Tora of Maimonides ${ }^{42}$, followed in his footsteps as far as non-Jewish documents were concerned. By the fourteenth century, this norm was well established despite the fact that, from a halakhic point of view, the scribe or notary appointed by the authorities were not different in status from a Christian court ${ }^{43}$. The validity of

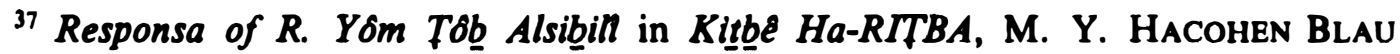
(ed.), New York 1957, pp. 133-180.

38 ADRET II, No 290.

39 ADRET II, No 111; ADRET III, Nos 15, 16.

40 S. Shilo, Dina' dé-Malkuta' Dina', Jerusalem 1975, pp. 340-342.

${ }^{4}$ R. Abraham Ben Ślomo Tazarte, Huqgat Ha-Dayyanim, II, Jerusalem 1971, chap. 239.

${ }^{42}$ Maggid Mišneh, on Mišneh Tord, Hilkdot Malweh we-Loveh, chap. $27,1$.

${ }^{43}$ R. Nisstm Gerond on R. Yishaq Alfasi, Mišnd Gittin, 10v. See also R. YishaQ Bar SeSEet Perfet, Sefer Sẻelót u-Térubobot, Lvov 1805, No 203. 
notarial acts according to $\mathrm{R}$. Zěrahyâ Ha-Levî depended on the official appointment of the notary and his good reputation. $R$. Zerrahyâ Ha-Levî informs us that this was the basis, ever since the days of Adret, for the recognition of the notarial documents in Catalonia in Jewish law ${ }^{44}$. It is significant that halakhists such as Adret considered the royal courts - of their time free of corruption and bribery. This was due in no small measure to the high regard which Jewish jurists had for the king.

The qèhilla or aljama enjoyed a fairly extensive degree of selfgovernment that had no parallel in medieval Christian Europe. While the Jews saw their autonomy as the extension of the selfgovernment inherent in Jewish law and tradition, which they upheld of their own free will, the leaders of Spanish Jewry were totally aware that Jewish autonomy was the result of royal concession. Adret was of the opinion that the qéhillâ's right to legislate and rule by an authority which was not vested in it by the Torah, had nevertheless the same validity as Torah-law ${ }^{45}$. Aware of the circumstances prevalent in the Exile, he admitted that the ordinances of the qehil.la were not necessarily derived from Talmudic law ${ }^{46}$. The community's authority to punish transgressors comes from the "government of the country" and its jurisdiction in several fields was not in accordance with the "laws of the Torah" but rather with the "authorization of the government». The realism in Adret's statement is noteworthy ${ }^{47}$.

Paradoxically, the rabbis of Spain used the principle «the law of the kingdom is law" to strengthen the Jewish judicial system. The acceptance of certain principles and laws from Christian society enabled the Jews to adapt themselves to new conditions without causing irreparable damage to their existence as a separate ethnic, religious and cultural group.

Eminent halakhists and communal leaders sought quite often the king's help to strengthen Jewish self-government and impose their authority on the Jewish public. Royal interference in Jewish internal 168.

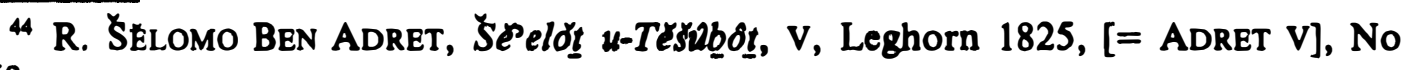
185.

${ }^{45}$ R. Šlomo Ben ADRET, Šeelot u-Tesuabobt, IV, Vilna 1881, [= ADRET IV], No

46 ADRET III, No 397.

${ }^{47}$ ADRET IV, 311 = VIII, 279. 
affairs came frequently at the instigation of the Jews themselves ${ }^{48}$. Besides such initiatives, considered legitimate by the community leaders, there was a parallel uncontrollable trend of malsinut, informers who by their reports to the authorities jeopardized Jewish autonomy altogether. The word "malsin" penetrated into medieval Castilian, a word of Jewish origin that became the keyword for treason and treachery. The bêt-din often became powerless, not because the Chistian authorities wished to paralyze it, but because Jews turned to Christian power in their struggle with their fellowJews ${ }^{49}$. Jewish society was destined to pay a heavy price for its readiness to turn to the Crown to settle internal strife. This behaviour undermined the very foundations of Jewish existence in Spain.

Compared to large sectors of Christian society who were deprived of the freedom of movement, the Jews enjoyed a large measure of freedom in their movement. The Jews' freedom of movement within the limits of royal domain did not affect their status as the king's property. Furthermore, the Jew's movement throughout the kingdom coincided with the king's financial interests. Attempts by communities to control the movement or restrict the emigration of their members


expressed in no uncertain terms by Catalan rabbis in 1346:

It has been agreed since time immemorial in the kings' courts that the Jews are free people, and kings cannot stop them from moving wherever they please .... The Jews are free as the knights, to go wherever they wish... ${ }^{s !}$.

Finally, Spanish rabbis found it convenient that the Crown punished Jews for certain crimes. In most cases the Jews had no choice, but it is significant that rabbis felt the need to justify it ${ }^{32}$.

48 For the Crown of Aragon, for instance, see F. BAER, Die Juden, Nos 131, 144, 163, 164: J. REGNE, History, Nos 2.448, 2.451, 2.452, 2.464, 2.589, 2.599, 2.908, 2.919; Archivo de la Corona de Aragón, Procesos de Audiencia 506/14.

49 ADRET II, Nos 19, 84. On Jewish informers in Spain see D. KAUfMaN, "Jewish Informers in the Middle Ages" JQR VIII (1891) 217-238; F. DE BOFARULL Y SANS, "Los judíos malsines", BABLB VI (1919) 207-216.

50 F. BAER, Die Juden, 224a, p. 314, clause 1.

${ }^{51}$ F. BAER, Die Juden, p. 315 , clause 2. In 1.354, royal confirmation of this freedom was sought by Catalan and Valencian Jews, ibid., No 253, p. 357, clause 35.

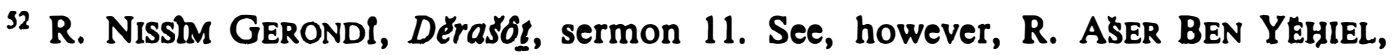

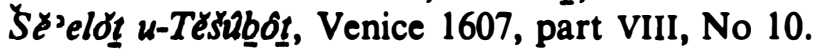


The attitude of the rabbinic authorities of Spain to Christian power was deeply influenced by the extensive involvement of the Jews in the life of the country. Their political, economic and cultural activities drew them nearer to the surrounding society which left a deep impact on every aspect of Jewish life. For the monarch the Jews were an invaluable asset whose protection was of crucial importance. The Jewish policy of most Iberian kings was seen by the Jews as benevolent. Compared to other rulers of Christian Europe, the kings of Castile, Aragon and Navarre were «benevolent kings». They were the Jews' only solid and reliable allies and the Jews' attitude to their power and authority was shaped accordingly.

\section{RESUMEN}

La actitud de los judíos frente al poder cristiano en la España medieval está profundamente influenciada por dos factores: la tradicional actitud judia hacia los gobiernos no judios en el exilio y las condiciones cambiantes de la posición de los judíos en cualquier tierra o período dados. El importante papel desempeñado por los judíos en los dos grandes reinos de Castilla y Aragón los acercó más que nunca a las cortes cristianas. Las fuentes legales hebreas reflejan el respeto y amistad que sentían los líderes judíos hacia la realeza y los reyes en la península ibérica.

\section{SUMMARY}

The attitude of the Jews to Christian power in Medieval Spain is deeply influenced by two factors: The traditional Jewish attitude to the non-Jewish government in Exile and the changing conditions in the position of the Jews in any given land and period. The important role played by the Jews in the two major Iberian kingdoms of Castile and Aragon brought the Jews closer than ever to the Christian courts. Hebrew legal sources reflect the respect and friendship that Jewish leaders felt towards kingship and kings in the Iberian peninsula. 